\title{
LONGITUDINAL DEVELOPMENT OF THE SPINE AND SPINAL CORD IN HUMAN FETUSES
}

\author{
DESENVOLVIMENTO LONGITUDINAL DA COLUNA VERTEBRAL E MEDULA ESPINAL EM \\ FETOS HUMANOS
}

\section{DESARROLLO LONGITUDINAL DE LA COLUMNA VERTEBRAL Y MÉDULA ESPINAL EN FETOS HUMANOS}

\author{
Patricio Manzone ${ }^{1}$, Juan Armando Guidobono ${ }^{2}$, Daniel Forlino ${ }^{2,3}$ \\ 1. Hospital Pediátrico "Dr. Avelino Castelán", Resistencia, Chaco, Argentina. \\ 2. Universidad Nacional del Nordeste (UNNE), Facultad de Medicina, Corrientes, Corrientes, Argentina. \\ 3. Diagnóstico por Resonancia SA, Resistencia, Chaco, Argentina.
}

\begin{abstract}
Objective: The spinal cord extends from the foramen magnum to the sacrum in the human fetus at the beginning of the $2^{\text {nd }}$ quarter. However, the medullary cone is located at or above the level of the second lumbar vertebra at birth. The objective is to determine the difference between the rates of longitudinal growth of the spinal cord and the spine in human fetuses from the $13^{\text {th }}$ to the $22^{\text {nd }}$ week of gestation (WoG) using magnetic resonance imaging (MRI). Methods: Descriptive observational cross-sectional study of 24 stillbirths (13 $\hat{\sigma}, 11$ o), between the $13^{\text {th }}$ and $22^{\text {nd }}$ WoG, using spinal MRI. We recorded spine and spinal cord lengths in millimeters from the foramen magnum to the coccyx for the former and to the medullary cone for the latter. We identified the position of the medullary cone according to vertebral level and its correlation with the gestational age and the literature. Results: The spinal cord increased in length from 50 to 93 $\mathrm{mm}$, the spine from 57 to $137 \mathrm{~mm}$, and the medullary cone rose from S1 to L2. The rate of growth was $1.2 \mathrm{~mm} /$ day for the spine and 0.6 $\mathrm{mm} /$ day for the spinal cord. Conclusions: Discordance in the rate of normal longitudinal growth of the spine and spinal cord caused the medullary cone to rise from S1 level to L2 in the second trimester of pregnancy. These results allow an understanding of normal development and certain congenital malformations. Level of evidence IV; Case series.
\end{abstract}

Keywords: Fetal Development; Spine; Spinal Cord.

\section{RESUMO}

Objetivo: A medula espinhal (ME) estende-se desde o forame magno até o sacro no feto humano no início do $2^{\circ}$ trimestre. No entanto, ao nascimento, o cone medular localiza-se no nível da segunda vértebra lombar ou acima. O objetivo é determinar as diferenças na taxa de crescimento longitudinal da ME e da coluna vertebral (CV) em fetos humanos da $13^{a}$ à $22^{a}$ semana de gestação (SG) por meio de ressonância magnética (RM). Métodos: Estudo obsenacional transversal descritivo em 24 natimortos (13 ${ }^{\lambda}, 11$ q), com idades entre $13^{a}$ e $22^{a}$ SG, por RM da CV. O comprimento da CV e da ME foi registrado em milímetros, desde o forame magno até o cóccix na CV e até o cone na ME. Identificou-se a posição do cone de acordo com o nível vertebral, sua correlação com a idade gestacional e com literatura. Resultados: O comprimento da ME aumentou de 50 para $93 \mathrm{~mm}$, a CV de 57 para $137 \mathrm{~mm}$ e o cone medular subiu de S1 para L2. O ritmo de crescimento foi de 1,2 mm/dia para a CV e de 0,6 mm/dia para a ME. Conclusões: A discordância no ritmo do crescimento longitudinal normal da CV e da ME fez com que o cone medular subisse do nível de S1 até L2 no segundo trimestre de gravidez. Os resultados permitem compreender o desenvolvimento normal e certas malformações congênitas. Nível de evidência IV; Série de casos.

Descritores: Desenvolvimento Fetal; Coluna Vertebral; Medula Espinal.

\section{RESUMEN}

Objetivo: La médula espinal (ME) se extiende desde el foramen magnum hasta el sacro en el feto humano al inicio del $2^{\circ}$ trimestre. Sin embargo, el cono medular se ubica a nivel de la segunda vertebral lumbar o por encima en el momento del nacimiento. El objetivo es determinar las diferencias en el ritmo de crecimiento longitudinal de la ME y columna vertebral (CV) en fetos humanos desde la $13^{a}$ hasta la $22^{a}$ semana de gestación (SG) mediante resonancia magnética (RM). Métodos: Estudio descriptivo observacional transversal en 24 mortinatos (13 $\mathrm{O}, 11$ q), con edades entre la $13^{a}$ y $22^{a}$ SG, mediante RM de CV. Se registró la longitud de CV y ME, en milímetros, desde el foramen mágnum al coxis en la primera y hasta el cono en la segunda. Se identificó la posición del cono según el nivel vertebral y su correlación con edad gestacional y literatura. Resultados: La ME incrementó su longitud de 50 a $93 \mathrm{~mm}$, la CV de 57 a $137 \mathrm{~mm}$ y el cono medular ascendió desde S1 hasta L2. El ritmo de crecimiento fue de $1.2 \mathrm{~mm} /$ día para la CV y de $0.6 \mathrm{~mm} /$ día para la ME. Conclusiones: La discordancia en el ritmo de crecimiento longitudinal normal de la CV y ME determinó que el cono medular ascienda desde el nivel S1 hasta L2 en el segundo trimestre de gestación. Los resultados permiten comprender el desarrollo normal y ciertas malformaciones congénitas. Nivel de evidencia IV, serie de casos.

Descriptores: Desarrollo Fetal; Columna Vertebral; Médula Espinal. 


\section{INTRODUCTION}

The development of fetal ultrasonography and magnetic resonance imaging significantly improved the accuracy of intrauterine diagnosis of open and closed defects of the neural tube. ${ }^{1}$

The hypertrophy and shortening of the filum, also known as the tight filum terminale, is a simple spinal dysraphism without subcutaneous masses; ${ }^{2}$ it can cause tethered spinal cord syndrome in the child preventing the normal ascent of the medullary cone. ${ }^{3-5}$ This condition can give symptoms in childhood, or even in adulthood, linked to neurological deficit from spinal cord traction, but also as repeated episodes of meningitis or spinal abscesses. ${ }^{1}$ Structural defects of this type arise from an error in the normal morphogenesis of the filum terminale and the medullary cone ${ }^{6}$ during the "retrogressive differentiation" phase, in which the caudal medulla atrophies, forming the filum and the coccygeal ligament, and the cone ascends progressively. ${ }^{1,3}$

Now, the spinal cord extends from the foramen magnum to the sacrum in the human fetus at the beginning of the second trimester and subsequently ascends. At birth or at two months of life, it is located at the level of the second lumbar vertebra or above (L1-L2), or in any case above the L2-L3 disc, (Figure 1) a position that it maintains throughout life. ${ }^{1,4,7,8}$ In fact, during childhood, once the spinal cord has reached its definitive level, growth of the spinal cord and the spine continue at the same rate and rhythm until adulthood. ${ }^{8}$

The normal rate of medullary ascent during the fetal period until reaching its final level has not been fully clarified. It has been shown that after thirty five weeks the cone is located near its final level ${ }^{7,9}$ and there are previous studies that have demonstrated the progressive ascent of the cone during the fetal period, relating it especially with the length of the fetus and with the vertebral level each week, $7,8,10$ though none has measured the differential growth speeds between the spinal cord and the spine. Some authors ${ }^{7}$ refer to the individual rate of spinal cord and spine growth, suggesting that it would determine the "relative ascent" of the cone, but they have not measured these speeds. Defining the normal and proportional rate could help to understand the pathological changes of this part of morphogenesis, which leads to the genesis of disorders like tight filum terminale.

The objective of our study was to determine the differences in the rates of longitudinal growth of the spinal cord and the spine in human fetuses from the 13th to the 22nd week of intrauterine gestation (WG) using magentic resonance (MR).

\section{METHODS}

A quantitative basic science field investigation was conducted through a descriptive observational non-probabalistic cross-sectional study of 24 stillbirths, (Figure 2) with ages between the 13th and 22nd weeks of gestation using MRs of the spine. These specimens were collected from the Developmental Anatomy Laboratory of the Facultad

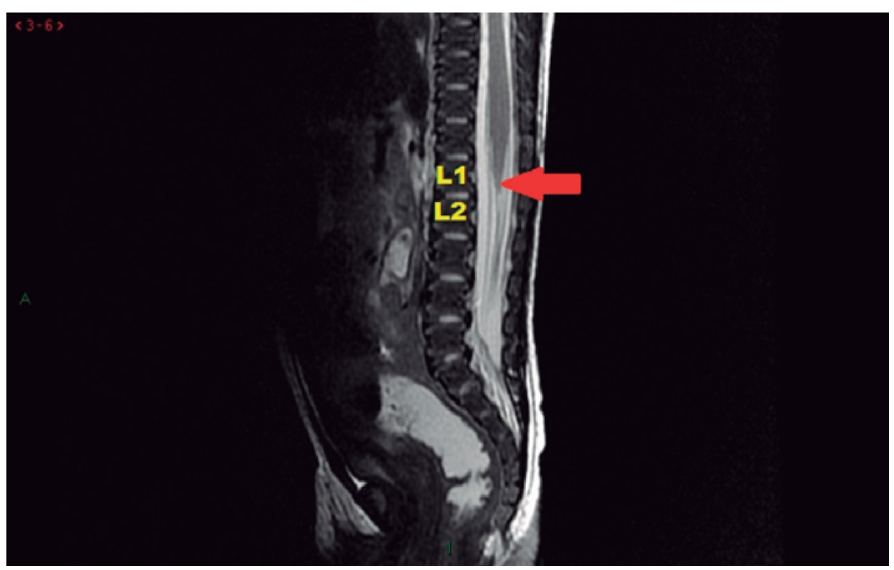

Figure 1. Magnetic Resonance Image (sagittal section in T2) of the spine of a normal female newborn showing the location of the cone at that age. de Medicina de la Universidad Nacional del Nordeste (UNNE), in Corrientes, Argentina. Since the study was conducted on specimens from a Museum of Anatomy, most of which had been archived there for many years, approval by an Institutional Review Board was neither requested nor required. There were also no data that linked the samples to any living or missing person. All the fetuses were in a good state of preservation and without malformations evident under microscopic inspection. For the MR study, a 1.5 Tesla (General Electric, model Brivo MR 355 1.5 T) apparatus with a dedicated 8-channel coil system was used. A volumetric T1 FSPGR (fast spoiled gradient echo) sequence was acquired with $\mathrm{TR}=8.7, \mathrm{TE}=3.1$, angle $=20^{\circ}, 2$ acquisitions, field of vision $160 \mathrm{~mm}$, matrix = 448x224 obtaining between 164 and 1801 $\mathrm{mm}$ sagittal images, depending on the size of the fetus, to visualize the entire anatomy. The images were processed at a workstation (General Electric Advantage Workstation 4.6).

The gestational age of each specimen was determined by the fetal biometry tables commonly used in ultrasound. Thus, the femoral length and the biparietal diameter were recorded in millimeters. Both parameters were obtained two times and averaged. For the estimation of the age, the 50th percentile of the tables prepared by Kurmanavicius J. et all. ${ }^{11,12}$ were considered. In addition, automatic age determination was peformed with the same measurements using ultrasound equipment (Esaote, MyLab 60) without finding differences between the two determinations.

The length of the spine and spinal cord were then recorded in millimeters from sagittal images, from the foramen magnum to the coccyx and from the foramen magnum to the cone, respectively. (Figure 3) In addition, the position of the medullary cone was identified according to the vertebral level. The data were correlated with gestational age.

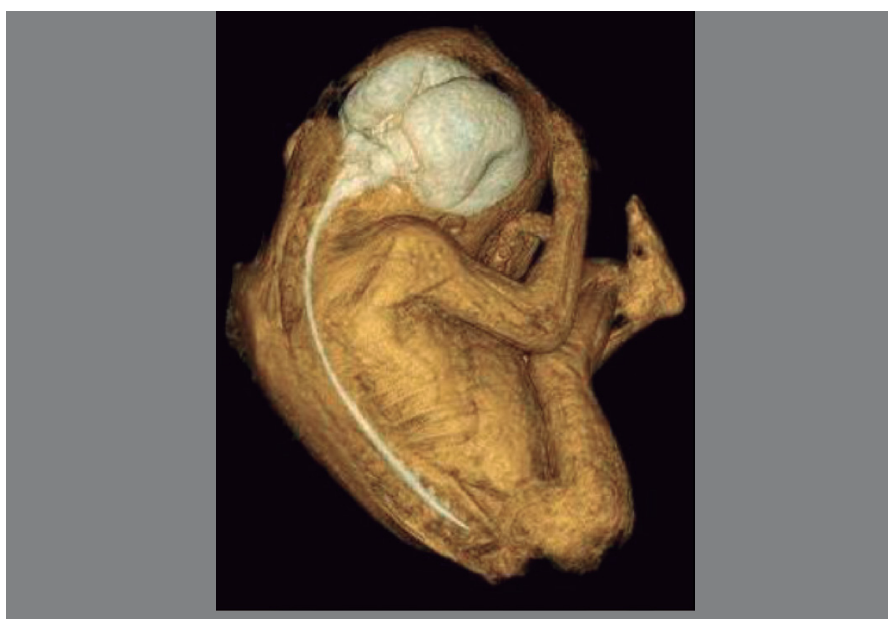

Figure 2. 3D Reconstruction with magnetic resonance and transparencies of a specimen used in the study

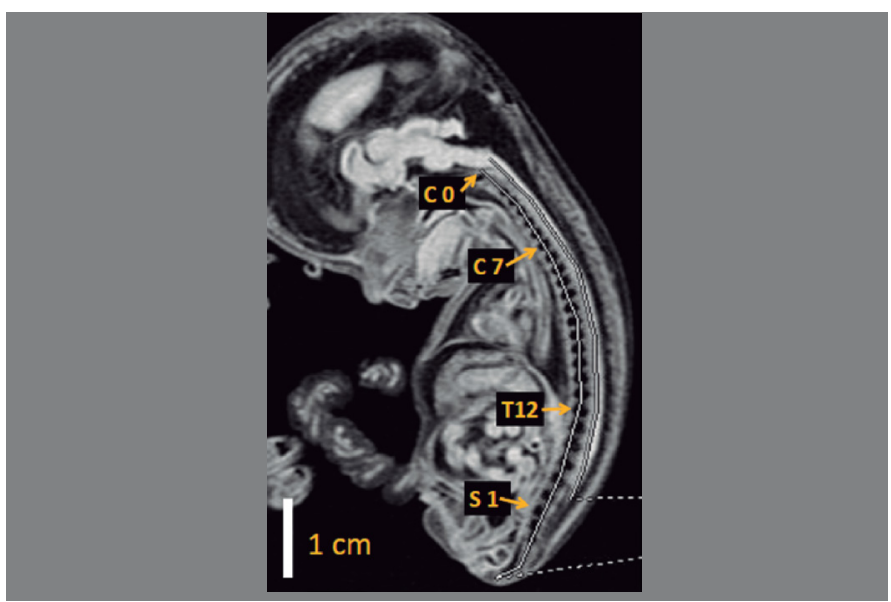

Figure 3. Measurement of the lengths of the Spinal Cord and the Spine. 
The speed of growth of the spine and spinal cord were calculated arithmetically using the mean lengths and the difference in days between the youngest and the most developed specimens. The Mann-Whitney $U$ test was used to verify the homogeneity of the samples in terms of sex and the length measurements performed and Fisher's exact test was used to assess the differences between the highest and lowest cone termination levels by sex.

\section{RESULTS}

The results are summarized in Table 1. First, the entire fetal anatomy was evaluated through images and specimens with macroscopic malformations of any organs were eliminated, thus ensuring that all the fetuses to be included in the study were without malformations or dysmorphies. Ten (10) specimens had the cone at level L3, 5 at level L4, 4 at level S1, 3 at level L5, and 1 each at levels L2 and S2. The Fisher's test resulted in no statistical differences ( $p=$ 0.2445 ) for the comparison between the sexes of the highest and lowest levels of the termination of the medullary cone.

The spinal cord increased in length from 50 to $93 \mathrm{~mm}$, the spine from 57 to $137 \mathrm{~mm}$, and the medullary cone ascended from S1/ S2 to $\mathrm{L} 2$ between the $13^{\text {th }}$ and $22^{\text {nd }}$ weeks of gestation (Figure 4). There were statistically significant differences between the lengths of the spine in male and female fetuses $(p=0.4884)$ with the MannWhitney test, but not for the length of the spinal cord ( $p=0.6432)$. The mean growth rate observed was $1.2 \mathrm{~mm} /$ day for the spine and $0.6 \mathrm{~mm} /$ day for the spinal cord. The mean ascent verified during the entire trimester was four (4) vertebral segments (i. e., 4 bodies and 4 discs).

\section{DISCUSSION}

Different malformations, disruptions, and dysplasias can occur on the spine and spinal cord of the fetus in formation, secondary to intrinsic, extrinsic, and mixed factors. ${ }^{13}$

The formation of the spinal cord develops in three phases: gastrulation, primary neurulation, and secondary neurulation. ${ }^{9,14,15}$ After the closure of the neural groove at approximately 28 days of
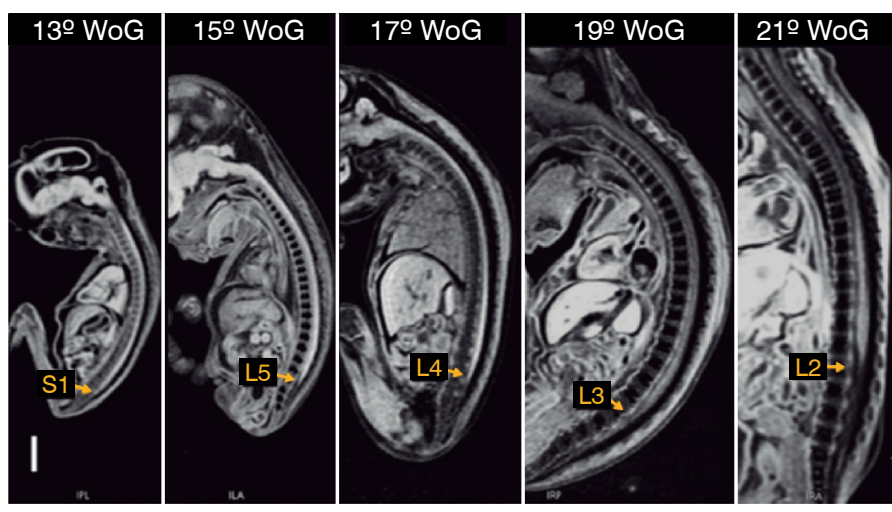

Figure 4. Example of the ascent of the cone by weeks of gestation.

gestation, the masses of cells caudal to the posterior neuropore tunnel down and form a channel that gives origin to the most distal portions of the spinal cord: the filum terminale and the medullary cone. ${ }^{6}$ In the third and final phase, at around 11 weeks, "retrogressive differentiation" occurs, in which the caudal structures undergo a programmed and orderly necrosis leaving the filum, the coccygeal ligament, and the terminal ventricle of the cone. . $^{1,9,10,16,17}$ It has been shown that only after this process does the disproportion between the growth rates of the spinal cord and the spine begin to be apparent. ${ }^{8}$ Coincidentally, in this study we found a growth rate of 1.2 $\mathrm{mm} /$ day for the spine and $0.6 \mathrm{~mm} /$ day for the spinal cord. (Table 2)

On the contrary, most spinal malformations originate during somitogenesis, especially in the segmentation phase, that is, during the embryonic period. ${ }^{18}$ However, the phenomenon of progressive caudal reduction of the spinal cord is a phenomenon of natural morphogenesis that is also seen to some extent in somites, although in a different period. The initial number of post-sacral somites decreases from eight $( \pm 2)$ to four $( \pm 1) .{ }^{19,20}$ Therefore, sacral vertebral anomalies as well as the most severe forms of lumbosacral agenesis, can find their pathogenic explanation either in the alteration of this phase $e^{6,19,20}$ or in the defects of the segmental formation of the notochord. ${ }^{21}$

Table 1. Summary of the results obtained from the different specimens.

\begin{tabular}{|c|c|c|c|c|c|c|c|}
\hline Specimen & Sex* & Ultrasound age\# & Average age ${ }^{* *}$ & $\begin{array}{l}\text { Length of the } \\
\text { Spine }\end{array}$ & $\begin{array}{c}\text { Length of the } \\
\text { Spinal Cord }\end{array}$ & $\begin{array}{l}\% \text { Spinal Cord in } \\
\text { terms of Spine }\end{array}$ & $\begin{array}{l}\text { Position of the } \\
\text { cone }\end{array}$ \\
\hline FMR004 & 1 & $13 w 2 d$ & 13 & 59 & 50 & 84.7 & S1 \\
\hline FMR013 & 1 & $13 w 5 d$ & 14 & 59 & 53 & 89.9 & S1 \\
\hline FMR005 & 1 & $14 w 6 d$ & 15 & 65 & 57 & 87.6 & S1 \\
\hline FMR002 & 1 & $15 w 5 d$ & 15 & 72 & 58 & 80.5 & L5 \\
\hline FMR006 & 1 & $16 w 3 d$ & 16 & 90 & 78 & 78 & L4 \\
\hline FMR011 & 1 & $15 w 6 d$ & 16 & 77 & 58 & 75.3 & L4 \\
\hline FMR001 & 1 & $16 w 6 d$ & 17 & 89 & 71 & 79.7 & L4 \\
\hline FMR027 & 1 & $16 w 6 d$ & 17 & 93 & 72 & 77.4 & L4 \\
\hline FMR010 & 1 & $17 w 4 d$ & 17 & 90 & 69 & 76.6 & L4 \\
\hline FMR016 & 0 & $19 w 5 d$ & 19 & 124 & 91 & 73.3 & L3 \\
\hline FMR026 & 1 & $19 w 3 d$ & 19 & 106 & 78 & 73.5 & L3 \\
\hline FMR022 & 0 & $19 w 2 d$ & 19 & 123 & 92 & 74.7 & L3 \\
\hline FMR017 & 1 & $20 w 5 d$ & 20 & 121 & 88 & 72.7 & L3 \\
\hline FMR020 & 0 & $19 \mathrm{w} 6 \mathrm{~d}$ & 20 & 118 & 84 & 71.2 & L3 \\
\hline FMR024 & 0 & $21 w 4 d$ & 21 & 131 & 90 & 68.7 & L3 \\
\hline FRM028 & 0 & $22 w 2 d$ & 22 & 143 & 97 & 67.8 & $\mathrm{~L} 2$ \\
\hline
\end{tabular}


The level of the medullary cone in the spine of the fetus is quite variable, but its normal position in the newborn is at the level of disc L2-L3 and it ascends to its final position at the level of or above disc L1-L2 between 2 months and 1 year of extrauterine life9. (Figure 1)

Our data coincided with the findings of Zalel et al. in their prospective ultrasonographic study of 110 gestations with fetuses between 13 and 40 weeks, ${ }^{22}$ in which almost all the fetuses under 18 weeks of gestation had the medullary cone at or below the level of vertebral segment L4. (Table 3) In the fetuses under 35 weeks of gestation, the cone was positioned between levels L2 and L5, while in those over 35 weeks of gestation the cone was positioned above level L3. ${ }^{7,9}$ At 39 weeks, the cone was in this location in $94 \%$ of the fetuses ${ }^{7}$. (Table 3)

Some authors ${ }^{7}$ maintain that the ascent of the cone is constant throughout the life of the fetus. Others have demonstrated the rapid ascent of the medullary cone before 35 weeks of gestation, ${ }^{8-10}$ as well as the appearance of disproportionate growth rates between the spine and the spinal cord during this period. ${ }^{8}$ Although Vettivel ${ }^{10}$ relates the growth and ascent of the medullary cone to the length of the fetus in his study, the latter can be easily correlated with gestational age ${ }^{23}$. (Table 4 and Figure 5) Our data confirm these findings, given that the speed of growth of the spine is double that of the spinal cord during

Table 2. Mean differential lengths (in $\mathrm{mm}$ ) of the spine and spinal cord by weeks of gestation.

\begin{tabular}{c|c|c}
\hline \multicolumn{3}{|c}{ Length in millimeters } \\
\hline WoG & Spine & Spinal cord \\
\hline $13-14$ & 57.25 & 50 \\
\hline $15-16$ & 75.6 & 63.6 \\
\hline $17-18$ & 95.16 & 71.83 \\
\hline $19-20$ & 118.33 & 86.66 \\
\hline $21-22$ & 137 & 93.5 \\
\hline
\end{tabular}

WoG: weeks of gestation.

Table 3. Position of the medullary cone by weeks of gestation.

\begin{tabular}{c|c|c|c|c|c|c}
\hline \multirow{2}{*}{$\begin{array}{c}\text { Weeks of } \\
\text { Gestation }\end{array}$} & \multicolumn{7}{|c}{ Position of the Cone } \\
\cline { 2 - 7 } & L2 & L3 & L4 & L5 & S1 & S2 \\
\hline 13 & & & & & 2 & 1 \\
\hline 14 & & & & & 1 & \\
\hline 15 & & & & 3 & 1 & \\
\hline 16 & & & 2 & & & \\
\hline 17 & & & 3 & & & \\
\hline 18 & & 3 & & & & \\
\hline 19 & & 4 & & & & \\
\hline 20 & & 2 & & & & \\
\hline 21 & & 1 & & & & \\
\hline 22 & 1 & & & & & \\
\hline
\end{tabular}

Table 4. Correlation between weeks of gestation, lunar months, weight, and length of the embryo or fetus (taken from Ullan Serrano, Ref. 23).

\begin{tabular}{c|c|cc}
\hline Lunar months & Weeks & $\begin{array}{c}\text { Crown-Rump length } \\
\text { in } \mathbf{~ c m}\end{array}$ & Weight in grams \\
\hline 1 & $4-8$ & 0.2 & $8-10$ \\
\hline 2 & $8-9$ & $4.7-5$ & $13-45$ \\
\hline 3 & $13-16$ & $6-8$ & $60-200$ \\
\hline 4 & $17-20$ & $9-14$ & $250-460$ \\
\hline 5 & $21-24$ & $15-19$ & $500-820$ \\
\hline 6 & $25-28$ & $20-23$ & $900-1300$ \\
\hline 7 & $29-32$ & $24-27$ & $1400-2100$ \\
\hline 8 & $33-36$ & $28-30$ & $2200-2900$ \\
\hline 9 & $35-36$ & $1-1$ & $3000-3400$ \\
\hline
\end{tabular}

the second trimester of pregnancy (Figure 6). However, in the sample examined here, the cone has a definitive position at 22 weeks of gestation, which is temporally prior to the bibliography consulted. In his study, Arthurs found only $23 \%$ of the fetuses with the cone positioned at level L3 or above. ${ }^{7}$ This difference between our findings and those of Arthurs et al. may be related to the formaldehyde preservation time of the specimens used in our study. (Figure 4)

Unlike what happens in open spinal dysraphism, occult dysraphic anomalies are usually not obvious at birth. ${ }^{1,3}$ And although a tethered spinal cord sindrome has also been described with the cone in the normal position, ${ }^{3,24}$ the fact that the ascent of the cone is almost complete during the first two trimesters of pregnancy is important ${ }^{25,26}$. (Table 3) The mean ascent of four (4) vertebral segments ( 4 bodies and 4 discs) during the second trimester that we observed in this study contrasts strongly with the mean ascent of one (1) to one and a half (1.5) vertebral bodies described by Arthurs ${ }^{7}$ for the third trimester and may be hypothetically due to the biological variability of the samples.

However, both the findings of our study and of others ${ }^{7,9,22}$ indicate that with ultrasonographic or magnetic resonance studies during pregnancy, it can be assumed that if after 35 weeks the medullary cone is below L2-L3, the spinal cord is in an abnormally low position and some caudal malformation may exist.

In a similar study, although with a larger case series, the authors could not establish either the sex or the race of the specimens, so demographic conclusions could not be drawn. ${ }^{7}$ Other studies ${ }^{10}$ have observed racial differences with respect to the vertebral level of the termination of the spinal cord, but no statistical differences between the sexes have been reported. ${ }^{10}$ In this study we found a difference between the sexes in the length of the spine but not of the spinal cord.

In any case, our work has some limitations to be noted. Among them, the prolonged time that the specimens remained in

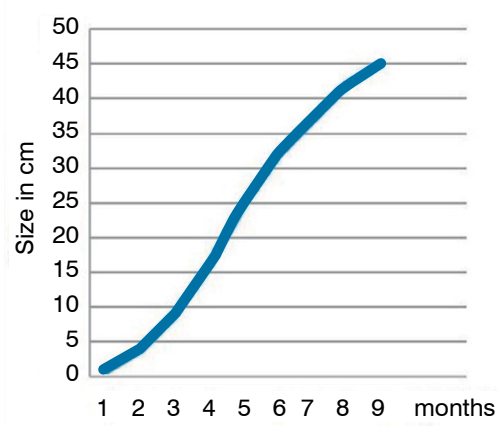

Figure 5. Correlation between weeks of gestation and size of the product (embryo/fetus) (taken from Ullan Serrano, Ref. 23).

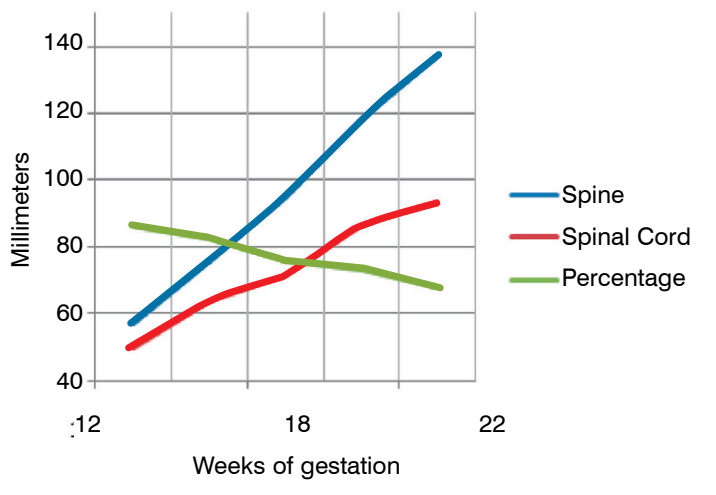

Figure 6. Correlation between the speeds of growth of the spinal cord and the spine. 
formaldehyde, possibly causing retraction of the central nervous system and distorting the acquired data, and the small number of specimens evaluated compared to other reports using the same technique. $^{7}$

\section{CONCLUSION}

The discordance between the normal longitudinal growth of the spine $(1.2 \mathrm{~mm} /$ day) and the spinal cord $(0.6 \mathrm{~mm} /$ day $)$ indicates that the medullary cone ascends from level $S 1$ to level $L 2$ from the $13^{\text {th }}$ to the $22^{\text {nd }}$ week of gestation. The results help to understand normal development and some congenital malformations, such as tethered spinal cord.

All authors declare no potential conflict of interest related to this article.

CONTRIBUTION OF THE AUTHORS: Each author made significant individual contributions to this manuscript. PPM - writing, review, statistical analysis; JAG - data collection, research project design. DF - writing, review, data collection, research project design.

\section{REFERENCES}

1. Bauman JA, Schwartz DM, Welch WC, Sutton LN. Chapter 31: Congenital Anomalies of the Spinal Cord. En: Herkowitz HN, Garfin SR, Eismont FJ, Bell GR, Balderston RA, editors. Rothman-Simeone The Spine, $6^{\text {th }}$ Ed. Philadelphia: Elsevier Saunders; 2011;573-607.

2. Rufener SL, Ibrahim M, Raybaud CA, Parmar HA. Congenital spine and spinal cord malformations-pictorial review. Am J Roentgenol. 2010;194(3 supplement):S26-37.

3. Abd-El Barr MM, Huang KT, Scott RM, Proctor MR. Chapter 35: Congenital Anomalies of the Spinal Cord. En: Garfin SR, Eismont FJ, Bell GR, Fischgrund JS, Bono CM, editors. Rothman-Simeone and Herkowitz's The Spine; $7^{\text {th }}$ Ed. Philadelphia: Elsevier Saunders; 2018;641-59.

4. Barkovich AJ. Pediatric neuroradiology, 4th ed. Philadelphia, PA: Lippincott Williams \& Wilkins; 2005.

5. Greene S, Ellenbogen R. Congenital Malformations of the Brain and Spinal Cord: 2005. En: Fuhrman BP, Zimmerman JJ, editors. Pediatric Critical Care Medicine. Maryland Heights: Mosby-Year Book;2006.

6. Jones KL. Smith's Recognizable Patterns of Human Malformation, $6^{\text {th }}$ Ed. Philadelphia: Elsevier;2006.

7. Arthurs OJ, Thayyil S, Wade A, Chong WK, Sebire NJ, Taylor AM. Normal ascent of the conus medullaris: A postmortem foetal MRI Study. J Matern Fetal Neonatal Med. 2012;26(7):697-702

8. Barson AJ. The vertebral level of termination of the spinal cord during normal and abnormal development. J Anat. 1970;106(Pt 3):489-97.

9. Widjaja E, Whitby EH, Paley MNJ, Griffiths PD. Normal Fetal Lumbar Spine on Postmortem MR Imaging. Am J Neuroradiol. 2006:27(3):553-9.

10. Vettivel S. Vertebral level of the termination of the spinal cord in human Fetuses. J Anat 1991;179:149-61

11. Kurmanavicius J, Wright EM, Royston P, Wisser J, Huch R, Huch A, et al. Fetal ultrasound biometry: 1. Head reference values. Br J Obstet Gynaecol. 1999;106(2):126-35.

12. Kurmanavicius J, Wright EM, Royston P, Zimmermann R, Huch R, Huch A, et al. Fetal ultrasound biometry: 2. Abdomen and femur length reference values. Br J Obstet Gynaecol. 1999:106(2):136-43.

13. Graham JM. Smith's Recognizable Patterns of Human Deformation; $3^{\text {rd }}$ Ed. Philadelphia: Saunders Elsevier;2007
14. Bess S, Varma V. Chapter 1: Embryology and Anatomy: Spine/Spinal Cord. En: Akbarnia BA, Yazici M, Thompson GH, Editors. The Growing Spine. Berlin Heidelberg: Springer-Verlag; $2011 ; 3-12$.

15. Akalat N. Chapter 21: Spinal Dysraphism. En: Akbarnia BA, Yazici M, Thompson GH, Editors The Growing Spine. Berlin Heidelberg: Springer-Verlag; 2011;269-79.

16. Kunitomo K. The development and rejection of the tail end of the caudal end of the spinal cord in the human embryo. Contributions to Embryology. 1918;161-197.

17. Streeter GL. Factors involved in the formation of the filum terminale. Am J Anat. $1919 ; 25(1): 1-11$.

18. Sponseller PD, Ting BL. Chapter 22: Congenital Scoliosis. En: Herkowitz HN, Garfin SR, Eismont FJ, Bell GR, Balderston RA, editors. Rothman-Simeone The Spine, 6th Ed. Philadelphia: Elsevier Saunders; 2011;374-84.

19. Bono CM, Parke WW, Garfin SR. Chapter 1: Development of the Spine. En: Herkowitz HN Garfin SR, Eismont FJ, Bell GR, Balderston RA, editors. Rothman-Simeone The Spine, $6^{\text {th }} \mathrm{Ed}$. Philadelphia: Elsevier Saunders; 2011;3-14.

20. Bono CM, Bhalla A, Garfin SR. Chapter 1: Development of the Spine. En: Garfin SR, Eismont FJ, Bell GR, Fischgrund JS, Bono CM, editors. Rothman-Simeone and Herkowitz's The Spine, $7^{\text {th }}$ Ed. Philadelphia: Elsevier Saunders; 2018;3-15.

21. Rossi A, Biancheri R, Cama A, Piatelli G, Ravegnani M, Tortori-Donati P. Imaging in spine and spinal cord malformations. Eur J Radiol. 2004;50(2):177-200.

22. Zalel Y, Lehavi O, Aizenstein O, Achiron R. Development of the Fetal Spinal Cord. Time of Ascendance of the Normal Conus Medullaris as Detected by Sonography. J Ultrasound Med. 2006;25(11):1397-401.

23. Ullan Serrano J. Embriología general: Introducción al desarrollo humano. Pamplona: Ediciones Universidad de Navarra, 1993.

24. Warder D, Oakes W. Tethered cord syndrome and the conus in a normal position. Neurosurgery. 1993:33(3):374-8.

25. Robbin ML, Filly RA, Goldstein RB. The normal location of the fetal conus medullaris. J Ultrasound Med. 1994;13(7):541-6.

26. Wolf S, Schneble F, Tröger J. The conus medullaris: time of ascendance to normal level. Pediatr Radiol. 1992;22(8):590-93. 